\title{
Menjadi Manusia Spiritual-Ekologis Di Tengah Krisis Lingkungan Sebuah Review
}

\section{Frederikus Fios}

Character Building Development Center, Bina Nusantara University, Jakarta, E-mail: fios@binus.ac.id

Diterima: 4 April 2019

Direview: 24 Juni 2019

Diterbitkan: 31 Juli 2019

Hak Cipta @ 2017 oleh Penulis (dkk) dan Jurnal Sosial Humaniora (JSH)

*This work is licensed under the Creative

Commons Attribution International License (CC

BY 4.0).

http://creativecommons.org/licenses/by/4.0/ Open Access
Subject Areas: Religion

\begin{abstract}
Abctract
Natural damage resulting from development activities committed human beings cannot be avoided. The deforestation is happening reduces the amount of forest area of Indonesia from Sabang to Merauke. The cause of the damage to our human nature as a subject of the spiritual-ecological. The materialist economic paradigm of mastering the mindset of human. The primacy of the spiritual-ecological neglected in development activities. This research aims to find an alternative relevant human model to restore nature in the midst of a crisis of the global environment and the context of Indonesia in particular. This paper is developed using the method especially ethical reflection. Finding a spiritual ecological thought as ontological basic human life in harmony with nature. Become a spiritual-ecological human being capable of providing solutions to the environmental crisis that happened an minimize the environmental crisis for the sake of ecological sustainability of creation.
\end{abstract}

Keywords: human; spiritual; ecological; crises; environmental.

\section{Pendahuluan}

Persoalan relasi manusia dan alam tidak pernah selesai dalam kenyataan hidup kita. Isu lingkungan hidup terus menggelisahkan umat manusia di planet bumi ini. Krisis lingkungan hidup menjadi titik perhatian berbagai pemimpin negara dunia dan ilmuwan yang peduli untuk berpikir dan berpraksis mengatasi kerusakan (krisis) alam lingkungan yang terjadi. Asumsi utama penyebab krisis alam disebabkan oleh ulah subjek manusia: pola pikir materialistis, antroposentris, saintisme, gaya hidup konsumtif, kebijakan pembangunan yang tidak ramah lingkungan. Semua ini melekat erat (inherent) pada diri kita manusia sebagai subjek, pelaku moral dalam realitas kehidupan.
Pertanyaannya: bagaimana posisi manusia dalam alam? Bagaimana sains modern dihadapkan dengan agama dan spiritualisme? Bagaimana cara hidup materialistis berhadapan dengan spiritualitas? Haruskah keduanya (materi dan spiritual) saling bertentangan? Prototipe manusia seperti apa yang relevan sebagai model alternatif masa kini untuk menciptakan tatanan dunia ekologis menuju keberlanjutan kehidupan kosmik yang lebih baik? Pertanyaan-pertanyaan inilah yang akan coba direfleksikan lebih lanjut dalam paper ini.

\section{Hasil Penelitian dan Pembahasan}

Fenomena Krisis Lingkungan yang Menantang 
Wacana mengenai krisis alam terus digaungkan berbagai pihak. Diskursus diperlukan untuk mendorong upaya pencarian horizon epistemik maupun teknik aplikatif baru yang relevan bagi upaya perbaikan dan peningkatan mutu kehidupan lebih baik untuk kebaikan ekologis. Ralph Metzner mengatakan krisis lingkungan global menjadi katalisator bagi pengkajian ulang nilai-nilai dan pengandaian-pengandaian berjangkauan luas dalam setiap bidang pengetahuan dan penyelidikan kita manusia. Analisis spekulatif menunjukkan paradigma atau pola pikir manusia yang didasarkan atomistik-mekanistik memicu lahirnya krisis alam lingkungan global. Pola ini melahirkan sikap-sikap destruktif manusia yang bermuara pada krisis alam lingkungan seperti polusi dalam berbagai dimensinya yang berakibat fatal untuk kehidupan umat manusia dan spesis biologis lain dalam alam. Polusi menjadi masalah penting dan objek politik kepedulian ekologi dunia industri (Naess: 1989, pp. 138- 140) dan pemerintah negara-negara dunia belakangan ini bahkan akan berlangsung hingga masa depan.

Tidak pedulinya manusia pada kualitas nilainilai spiritual alam, etika dan estetika alam diasumsikan turut memperparah krisis alam lingkungan global. Banyak pemikir menungkapkan argumentasi spekulatif-teoretis bahwa salah satu akar katastrofa (petaka) ekologis dewasa ini terjadi karena kesalahan pihak manusia (human error). Kendatipun perlu dibedakan juga bahwa tidak setiap bencana alam itu disebabkan ulah manusia, karena ada bencana yang memang disebabkan oleh proses dan fenomena dinamis natural intrinsik alam itu sendiri. Dinamika pemikiran kontemporer menunjukkan bahwa akar penyebab malapetaka lingkungan alam terletak dalam sikap, nilai, persepsi, dan pandangan dunia dasar (masyarakat industrial-teknologis global) yang kita pegang dalam mempersepsikan alam. Allan Marshall menegaskan asumsi ini dengan menunjukkan gejala fasisme ekologis dari pihak manusia atas alam. Akar fasisme ini terletak pada sesat pikir manusia yang menciptakan pemisahan rasional antara subjek manusia dengan alam. Alam merupakan satuan organisme yang terpisah dari diri manusia. Fasisme ekologis bermuara pada ikhtiar pencapaian idealisme kesejahteraan material manusia secara ekonomis saja. Manusia mengusahakan kesejahteraan dirinya di satu sisi, namun di sisi lain ia melakukan tindakan eksploitasi sewenang-senang atas alam sebagai objek. Fasisme ekologis terarah pada pencapaian tujuan-tujuan ekonomis-material untuk mengatasi masalah nyata dunia seperti yang dilansir oleh Roy E. Allen antara lain: perubahan iklim, kemiskinan, ketidakadilan sosial, konflik sosial, instabilitas moneter bahkan krisis politik pemerintahan negara-negara dunia untuk memulihkan ekonominya. Eksploitasi alam terus berlangsung sehingga lama-kelamaan dunia bergerak menuju kepunahannya. Fenomena ini disebut oleh M. Gorke dengan istilah "The Death of Our Planets Species", ancaman kematian spesies makhluk hidup di planet bumi termasuk ancaman untuk umat manusia sejagat. Bahkan pelaksanaan pembangunan yang digencarkan di segala bidang untuk memenuhi kebutuhan manusia membawa dampak negatif pada hilangnya makhluk hidup lain (biodeversity) dalam komunitas ekosistem alam. Banyak spesies hewan dan tumbuhan yang mulai punah bahkan hilang sama sekali dari kehidupan ini akibat pembukaan lahan pertanian, perkebunan, perkotaan, perumahaan, perkantoran, kawasan industri dll. Realitas biodiversitas dan jejaring 
ekosistem alam sebagai salah satu aspek penting penyanggah keberlanjutan ekologi terancam menyusut dan hilang.

Dalam konteks Indonesia, kerusakan ekologi alam sungguh memprihatinkan bahkan berada di titik nadir memprihatinkan. Kawasan hutan Indonesia terancam kelestariannya. Perluasan kepentingan bisnis dunia industri untuk mengejar akselerasi logika kemajuan ekonomi membuka peluang bagi tindakan eksploitasi sewenang-senang atas alam bahkan sering kali dengan cara membakar hutan yang dilakukan secara sengaja melibatkan subjek manusia. Fakta empirik miris $40 \%$ areal hutan Indonesia hilang akibat pembukaan hutan larangan (hutan lindung) sebagai lahan bisnis sehingga areal hutan di hampir semua daerah berkurang dari tahun ke tahun. Perilaku membakar hutan menjadi hal lumrah dalam pembukaan lahan industri baru di Pulau Sumatera dan Kalimantan. Ditambah lagi dengan praktik penambangan liar sporadis di berbagai tempat mendatangkan masalah serius bagi lingkungan alam Nusantara. Data lain menunjukkan luas areal hutan Pulau Jawa semakin berkurang dan kini tersisa $11 \%$ saja sehingga berpotensi melahirkan bencana ekologis tanah longsor dan banjir bandang. Presentasi kecilnya areal hutan ini mirip dengan kasus di Sumatera yang hingga kini hanya memiliki 10\% saja areal hutan tutupnya. Areal hutan Kalimantan pun semakin sedikit karena banyak perusahaan asing maupun domestik membuka pertambangan batu bara dan perkebunan sawit untuk tujuan bisnis (industri) tanpa memperhatikan keseimbangan ekologis.

Fenomena di atas mau menunjukkan bahwa ada persoalan serius dalam konteks cara pikir, sikap dan tindakan kita manusia dalam relasi dengan alam khususnya dalam implementasi aktivitas pembangunan yang kita lakukan. Tampaknya manusia lebih mementingkan logika/argumentasi keuntungan ekonomi ketimbang sisi kebaikan alam. Relasi manusia dengan alam terdistorsi. Pandangan materialisme alam lebih dominan ketimbang sisi spiritualismenya.

\section{Kontradiksi Sains dengan Pandangan Spiritualisme-Religius}

Deskripsi krisis alam dan penyebabnya pada uraian sebelumnya, secara spekulatif, menunjukkan adanya praktik eksploitasi atas alam dunia disebabkan oleh pandangan dasar manusia atas alam yang dipersepsikan secara pincang (tidak berimbang), alam hanya dilihat sebagai realitas material belaka. Pandangan ini sebetulnya berakar pada pandangan ilmuwan atau saintis modern Newtonian-Cartesian yang sudah bercokol berabadabad lamanya dalam panggung pemikiran filsafat ilmu pengetahuan. Pandangan ini dipertegas dengan hadirnya pemikiran atomisme-logis ilmiah yang memisahkan pengetahuan dari nilai. Logika lebih penting dari etika. Materi lebih penting dari non materi. Fisik lebih penting dari non fisik/spiritual/roh.

Atomisme logis mempersepsikan alam sebagai mesin-mekanistik saja, nilai-nilai intrinsik alam dieliminasi bahkan direduksikan pada pemahaman atau logika pandangan instrumentalmekanistik. Paradigma ini sangat berbahaya karena nilai-nilai intrinsik diabaikan lalu disubstitusi (digantikan) dengan paradigma mekanistikinstrumental dalam mempersepsikan alam. Skolimowski menegaskan: "But it was a perilous event, too, in that it led in the long run to a conception of the universe as a clock-like mechanism and to the gradual elimination of such 
elements of our knowledge as disagreed with that mechanistic view-including intrinsic values, which were replaced by instrumental values". Ketika alam dipersepsikan atau dibayangkan hanya sebagai pabrik mekanistik, maka alam dipersepsikan sebagai objek-objek fisik-material saja. Kemajuan material dan ukuran-ukuran kuantatif lebih penting daripada nilai-nilai kualitatif kehidupan. Kegembiraan utama materialistik diukur dengan skala kuantitatif; karena tidak ada kriteria nilai intrinsik kualitatif yang diterima, nilai instrumental semakin cenderung universal dan dianggap sebagai kriteria terakhir segala nilai dalam realitas kehidupan kita. Instrumen-materialisme menguasai horizon jagad pemikiran manusia modern bahkan kontemporer dalam memandang alam.

Pemahaman turunan atomistik tentang asal usul alam semesta dapat ditelusuri dengan bertitik tolak pada teori-teori bidang fisika-kimia dan biologi modern. Big Bang Theory merepresentasikan logika perluasan kosmos yang diasumsikan terjadi secara fisis-atomistik akibat gelombang-gelombang magnetik yang bergravitasi. Teori ini memegang teguh hipotesis dasar bahwa planet bumi dan alam semesta (kosmos) terjadi karena adanya proses-proses fisik-kimis yang intrinsik natural dalam alam itu sendiri, in se. G. Lemaitre (1927) mengasumsikan Big Bang sebagai penyebab terjadinya alam semesta (kosmos). Ahliahli fisika menalar terjadinya alam semesta ini dikuantifikasi berdasarkan hukum-hukum kekekalan energi dan dalil-dalil fisika kimia. Asumsi ini diperkuat oleh pernyataan salah satu astronom Inggris, Fred Hoyle yang mengatakan segala sesuatu materi dalam kenyataan alam semesta terjadi karena adanya ledakan dahsyat yang pernah terjadi di masa lalu. "...all the matter in the universe was created in one big bang at a particular time in the remote past". Pandangan-pandangan saintifik ini bersifat fisik-materialis mekanistik-atomistik. Bahkan aliran materialisme (prioritas keuntungan ekonomi) yang kemudian dikembangkan oleh Karl Marx pun bertitik tolak pada pandangan-pandangan dasar saintifik berparadigma atomistik-material ini. Litani ahli lain senada masih dapat diperpanjang sesuai dengan pemahaman dan referensi pengetahuan subjektif kita masing-masing. Di sini pulalah pintu masuk terjadinya tindakan eksploitasi atas realitas alam secara masif dan berkesinambungan.

Di sisi lain tidak sedikit pula pemikir yang mempersepsikan alam bukan sebagai hasil realitas material namun produk realitas non material/roh/spiritual. Para filsuf Yunani klasik seperti Aristoteles dan Plato setidaknya sudah membuka jalan itu. Aristoteles dalam De Anima I dan II mengatakan bahwa arche (jiwa) adalah esensi fundamental yang mendasari dan mengawali kosmos/alam semesta ini. Arche itulah prinsip dasar segala kehidupan di dalam alam.

Hal ini diperkuat lagi dengan pandangan teologis agama-agama dan aliran spiritualisme kosmik yang berpegang teguh pada konseptualisasi mendasar akan dasar ontologis alam semesta ini sebagai sesuatu yang dihadirkan dari yang non fisik. Bahwa dasar atau asal usul alam semesta ini disebabkan bukan oleh sesuatu yang fisik, melainkan oleh Substansi Metafisik. Pandangan agama-agama dan spiritualisme menekankan dimensi metafisika alam yang mengklaim bahwa alam semesta ini diciptakan atau dijadikan bukan karena fisik-mekanistik melainkan dijadikan secara rohani/spiritual karena adanya Kekuatan Metafisik yang tidak dapat direduksikan secara sederhana pada sesuatu yang tampaknya mekanistik saja. 
Bahkan secara doktrinal agama-agama yang kita kenal/anuti berkeyakinan kukuh bahwa alam semesta dijadikan atau diciptakan karena Penciptaan oleh Kuasa Ilahi Tuhan (Allah) sebagai Yang Maha Kuasa, Penyelanggara Kehidupan, Yang Transenden, Yang Supranatural. Keterangan dari Kitab Suci agama-agama maupun para teolog agama kita masing-masing tentu sudah mengulas hal ini secara rinci-detil.

Para filsuf bidang agamapun mendendangkan syair indah tentang spiritualisme alam. Filsuf Islam seperti Al Kindi, Ibnu Rusyd dan Ibnu Sina yang secara adequat cukup banyak dipengaruhi oleh pemikiran Aristoteles dan Plato, ikut mengklaim alam disebabkan oleh realitas metafisik. Beberapa filsuf Islam berpendapat bahwa alam semesta tidak bersifat kekal (terbatas), sementara. Al Kindi misalnya mengatakan alam adalah wujud-wujud spiritual yang tidak kelihatan, alam diciptakan oleh Zat Yang Tidak Kelihatan. Ibn Rusyd mengklaim bahwa Allah adalah penggerak pertama segala sesuatu (muharrik al- awall) di dalam alam, alam berasal dari Allah dan Allah bersifat tidak terbatas. Filsuf-filsuf dunia kristen seperti Thomas Aquinas, Teilhard de Chardin (evolusi alam adalah gerakan dari Allah menuju kembali kepada Allah, titik alfa menuju titik omega) menunjukkan alam sebagai realitas terbatas (tidak kekal) yang bergerak dinamis sesuai dengan hukum-hukum abadi Tuhan yang tak terbatas dan kembali kepada Tuhan sebagai Zat/Substansi Tidak Terbatas. Materi bersifat terbatas, sedangkan roh/Tuhan tidak terbatas. Pandangan Hindu dan Budha pun tak kalah menariknya tentang kisah penciptaan alam oleh Dewa (Tuhan) sebagai causa prima, sang pengada pertama yang mendahului adanya segala entitas ada di dalam alam.
Dunia filsafat mengungkapkan beberapa pengertian dari spiritual sebagai dasar terdalam segala sesuatu ada, yakni spiritual sebagai sesuatu yang :

a). Imaterial, bukan jasmani, tidak terdiri dari roh

b). Mengacu kepada kemampuan-kemampuan lebih tinggi (mental, intelektual, estetik, religius) dan nilai-nilai pikiran

c). Mengacu pada nilai-nilai manusiawi yang non material seperti keindahan, kebaikan, cinta, kebenaran, belas kasihan, kejujuran dan kesucian

d). Mengacu ke perasaan dan emosi-emosi religius dan estetik.

Dalam pemakaian sehari-hari istilah spiritualisme mengalami pengembangan arti dan makna. Spiritualisme selalu berkaitan dengan yang tidak terlihat, jiwa tidak kelihatan. Muncullah istilah yang dikenal dengan nama spiritualisme metafisik. Spiritualisme metafisik memiliki pandangan bahwa:

a). Realitas terakhir yang mendasari (landasan realitas) adalah roh/jiwa dunia yang meresapi alam semesta pada semua tingkat kegiatannya, sebab aktivitas dan tata/arah alam semesta, berguna sebagai satu-satunya penjelasan lengkap dan rasional akan eksistensi alam

b). Yang ada hanyalah Roh Absolut (dan rohroh terbatas seperti manusia) dan semua lainnya merupakan produk Roh Absolut itu. Banyak pemikir yang mengembangkan pemikiran menurut frame berpikir spiritual metafisik ini. Salah satunya tampak dalam nama seperti Baruch Spinoza (anima mundus, jiwa dunia), prinsip conatus essendi: alam memiliki jiwanya sendiri. Juga Plotinus yang sejak awal berbicara tentang prinsip emanasi, segala sesuatu di dalam alam material merupakan pancaran keluar dari suatu realitas yang metafisik. Dunia 
memiliki jiwa/spiritnya yang menghadirkan segala ada yang terlihat/kelihatan dalam realitas nyata/riil.

Kita hidup di dalam dunia kontemporer (sekuler) sekarang yang didominasi oleh mainstream (arus utama) pandangan sains modern dan materialisme profan yang begitu kuat merasuki pikiran, hati dan cara hidup kebanyakan orang di masa kini. Saintifikasi realitas dalam berbagai aspeknya ikut mengaburkan sendi-sendi nilai-nilai spiritual-religius dalam mempersepsikan alam. Bahkan ateisme (non religius) sebagai pemikiran maupun praksis diam-diam tertanam di dalam hati dan benak sebagian orang di planet bumi ini. Kita pun sepertinya berhadapan dengan gunung raksasa materialisme dan pandangan sains modern yang tentu berupaya untuk mematikan pandangan spiritualisme/religiositas alam semesta/kosmos ini. Materialisasi alam seakan menjadi primadona hidup di zaman kontemporer kini.

Dunia kita terfragmentasi dalam bipolaritas dikotomik pemikiran materialis atas alam versus spiritualisme alam. Di antara benturan dua (2) paradigma dalam mempersepsikan alam sebagai realitas material-fisik ataukah realitas spiritual/rohani ini, bagaimana sikap tepat kita untuk mensintesiskan dua frame kontradiktoris ini? Benturan dua (2) paradigma besar ini sangat terasa pengaruhnya, apalagi dominasi pandangan fisikmaterial seakan sulit dikendalikan dan ini berpotensi terus membuka arah pada tindakan eksploitasi atas alam. Lalu kita harus bagaimana? Adakah sosok manusia yang tampil sebagai terang atau oase untuk menyelamatkan spiritualisme alam? Bagaimana itu mungkin? Jika mungkin, masih seksikah kita hidup menjadi manusia spiritual-ekologis di zaman ini, di mana pencaharian ketinggian kuantitas materialisme dianggap sebagai kriteria nilai paling baik (terbaik) sebagai keyakinan materialisme sebagian masyarakat dunia sekarang ini?

\section{Manusia Spiritual Ekologis sebagai Oase di Tengah Krisis Lingkungan Indonesia}

Bagaimana kita menjadi manusia dalam hidup dan bagaimana kita hidup menjadi manusia di zaman ini? Inilah pertanyaan mendasar das sein tentang posisi 'berada kita sebagai manusia' dalam proses evolusi alam semesta bersama dengan entitas liyan (others). Ini pertanyaan penting untuk selalu kita manusia refleksikan dalam menjalankan hidup yang penuh, utuh. Makna eksistensi manusia sebagai subjek bisa dan hanya bisa dicapai dengan jalan berpikir filosofis reflektif. Filsafat hakikatnya adalah usaha kritis-rasional subjektif untuk terus bertanya diri tentang makna hakiki siapakah saya, who am I, apa makna eksistensiku dalam realitas kesemestaan ini. Dengan bertanya diri tentang siapakah subjek (aku, engkau, dia, kamu, kita, mereka) manusia terus menggugat diri, mempertanyakan hakikat eksistensi diri kita yang otentik di dalam realitas alam semesta.

Kita tentu tidak perlu berkonflik dengan pandangan materialisme atas alam. Karena klaim kebenaran setiap paradigma sulit kita ubah. Kita tentu perlu mulai dari diri sendiri dengan sadar diri bahwa hakikat kodrati kita sebagai manusia yakni makhluk spiritual sebagaimana klaim filosofis Henryk Skolimowski. Kita manusia adalah makhluk spiritual yang hidup. Spiritualitas merupakan hal esensial dari hakikat eksistensi manusia dalam ruang dan waktu. Spirituality is an articulated essence of the human condition of a given time. Dimensi spiritualitas itu merupakan suatu faktisitas, kenyataan yang terberikan di dalam totalitas realitas kemanusiaan kita. Manusia tidak dapat menolak 
fakta induk ini. Dimensi spiritualitas manusia bukanlah suatu unsur aksiden di dalam diri manusia, melainkan sungguh unsur esensial manusiawi yang mendefinisikan karakteristik kita manusia. Tanpa dimensi spiritual ini, maka manusia tidak dapat dikatakan hidup secara sungguh-sungguh manusiawi atau mengalami krisis spiritual. Ketika dimensi spiritual ini diambil atau hilang dari manusia, maka manusia tidak bisa dikatakan sebagai manusia, manusia sungguh-sungguh berakhir dengan sesuatu yang kurang sebagai manusia. Nasib kita berakhir tragis sebagai manusia dan makhluk yang memanusia.

"Spirituality is an articulated essence of human condition of a given time means that spirituality is not accidental, but essential to the human condition, is one of the defining characteristics of human condition. Without it the human condition can not be truly human. Take away spirituality from the make-up of the human being and you end up with something less than a human".

Pandangan Skolimowski ini menegaskan makna hakiki bahwa salah satu karakter dasar manusia in se yakni memiliki dimensi spiritualrohani. Setiap budaya manusia sudah memiliki tradisi-tradisi luhur di dalam mengembangkan dimensi spiritual ini. Pengembangan dimensi spiritual itu dikembangkan secara berbeda oleh manusia dalam setiap kebudayaan. Spiritualisme dikembangkan dalam budaya manusia di berbagai belahan bumi ini. Spiritualisme berkembang dalam konteks budaya tertentu. Spiritualisme merupakan suatu sikap independen-otonom dalam mengembangkan spiritualitas diri manusia. Menurut Skolimowski, setiap agama yang dimiliki oleh kita manusia, mengembangkan salah satu aspek dari spiritualitas pribadi manusia. Setiap agama mengekspresikan dimensi spiritualitas itu dengan cara-cara dan bentuk-bentuk yang berbeda. Ekspresi spiritualitas itu dihayati secara pribadi dengan mengeksplorasi intuisi dan jiwa manusia setiap individu. Di dalam eksplorasi jiwa itu manusia dapat mencapai kesatuan yang ultim tanpa kata dengan substansi metafisik yang lain. Kenyataan ini hanya mungkin dicapai manusia dalam kondisi keheningan, kesunyian, dan ketenangan yang adequat.

"Each major religion weaves a specific pattern out of our spiritual endowment and out of our spiritual propensities. Each major religion represents and perpetuas a specific form of spirituality. ....when we are indivually united with this ultimate oneness for which there is no word. Only in the silence of our unfathomable souls can we intuit the quintessential unity of all things spiritual".

Kapasitas spiritual manusia sebagai ciptaan Tuhan, menurut Skolimowski, seharusnya membuat manusia peka dan sadar diri untuk membina kualitas hubungan yang spiritual dengan ciptaan lain entah itu hubungan manusia dengan manusia, maupun hubungan manusia dengan alam. Dimensi spiritual merupakan instrumen yang mengarahkan sikap/tindakan manusia dalam relasi manusia dengan entitas yang lain dalam alam secara bermoral. Dimensi spiritual memungkinkan manusia untuk hidup secara rohani dalam menghayati totalitas eksistensinya dalam alam.

Bercermin pada Skolimowski, pertama-tama dan terutama tentu kita manusia harus sadar akan spirit of oneness, prinsip kesatuan segala sesuatu di dalam alam. Manusia dan alam tidak terpisah, melainkan satu kesatuan integral. Kita mulai dari diri kita sendiri sebagai manusia. Karena krisis 
lingkungan alam dalam berbagai bentuk multidimensional menuntut jawaban dari kita manusia sebagai makhluk berkesadaran dalam panggung alam semesta.

Pemikiran atomistik-mekanistik yang digunakan manusia dalam mempersepsikan alam mengetuk titik spiritual kemanusiaan kita untuk bertanya diri tentang bentuk perlakuan seperti apa yang pantas kita aktualisasikan dalam relasi dengan alam, hic et nunc (kini dan di sini). Usaha pencarian kemajuan ekonomi yang mengejar logika keuntungan material membawa manusia tersandera pada sebuah deadlock (jalan buntu) kerusakan ekologis yang penuh tragika. Manusia hidup dengan penuh kerakusan dan keserakahan, hidup tak pernah mengenal kata-kata "aku sudah cukup”! Manusia bernafsu memburu/memenuhi kata-kata "aku harus memiliki lebih banyak karena merasa belum cukup memiliki lebih banyak"! Manusia bermental hedonis, konsumtif, konsumeristis, tidak peduli dan berkompetisi untuk mengumpulkan akumulasi kekayaan material dalam jargon 'memiliki lebih banyak dalam hidup itu lebih baik daripada memiliki sedikit/kurang'.

Konsekuensinya, manusia mengeksploitasi alam secara sewenang-wenang. Manusia dan alam akhirnya sama-sama rusak, sama-sama hancur, sama-sama bergerak ke ambang kepunahannya. Di titik ini, manusia hidup penuh dengan resonansi melodi kegelisahan jiwa yang tidak berujung tepi. Hidup dan berada sebagai manusia ekologis ideal (spiritual-ekologis) jauh dari titik ideal. Ketika semua ini terjadi, manusia mengalami krisis nilai dan krisis eksistensial dalam fragmenta ziarah hidupnya. Krisis ini, pada gilirannya, menyeret manusia terperosok masuk ke dalam jurang gelap gulita kehidupan yang menggelisahkan jiwanya.
Zaman gelap kehidupan ditandai ketiadaan makna otentik hidup menjadi manusia sebagai salah satu bagian kecil dari komunitas alam semesta mahaluas ini. Kegelapan itu bukan pertama-tama menghantui alam, melainkan menciderai dan membelenggu pribadi manusia sebagai persona yang berpikir, merasa dan bertubuh. Sumber kegelapan diri berakar dalam insting kerakusan, ketamakan, keserakahan, mental hedonistik-egoistik, life style dalam kemasan konsumeristik yang membuat manusia buta sehingga tidak mampu membuatnya melihat terang (light) yang sesungguhnya. Padahal, manusia sebetulnya sedang tinggal di dalam alam sebagai home of light, rumah terang yang seharusnya mampu melihat terang dan bahkan berfilsafat tentang terang itu. Seandainya saja manusia bisa melihat terang itu, maka ia bisa menjadi pribadi yang mampu menerangi others. Namun faktanya tidak demikian. Karena buta (tidak sadar), maka manusia terus saja bersikap arogan terhadap alam. Alam terus dibuat menangis, dikorbankan, diobjekkan dalam tindakan eksploitasi akibat proyeksi nafsu instingtif manusia yang buas, egoistik, dan destruktif. Alam yang sejatinya adalah juga subjek moral, jauh dari konsientisasi dan kesadaran spiritual manusia sebagai pelaku moral yang seyogyanya perlu memperlakukan others secara spiritual. Manusia senang berada pada status quo titik gelap daripada bergerak menuju zona titik terang. Manusia lebih mencintai kegelapan daripada mencintai terang. Manusia lebih ingin melihat titik gelap, daripada melihat titik terang. Ketika kondisi ini terus terpolakan secara sistemik di dalam struktur kepribadian manusia, kita manusia tidur panjang dalam ilusi ketaksadaran diri yang memuakkan dan tidak ideal secara spiritual. 
Sikap-sikap keutamaan rohani/spiritual seperti: cinta kasih, simpati, solidaritas, dan altruis pada others jauh dari kesadaran rasional dan penghayatan praksis hidup manusia. Inilah lukisan sketsa wajah terpampang manusia kontempoprer yang terciderai, namun terpaksa saja hidup dalam senyum hambar untuk sekadar mempertahankan diri (survival for the fittest) di era masa kini. Lalu apakah manusia harus tetap menjadi 'sosok rakus' di dalam kegelapan zaman kapitalis kini yang seolaholah menghipnotis setiap orang untuk melihat ke arah nokta terang yang sejatinya adalah terang yang palsu? Tentu tidak! Kita membutuhkan sebuah jawaban!

Kita membutuhkan suatu transformasi konstruktif dalam pola pikir, pola sikap dan pola tindakan kita untuk dapat hidup bermakna menjadi manusia dalam kebersamaan dengan komunitas ekologis, yang lain dalam alam! Kita membutuhkan sebuah revolusi cara hidup dan revolusi karakter pribadi, dari diri yang belum ideal menuju diri yang lebih ideal, dari diri yang belum spiritual menuju diri yang lebih spiritual dalam bentangan alam semesta. Inilah waktunya kita reborn, lahir kembali dalam alam untuk menjadi manusia baru: manusia yang lebih baik, manusia yang lebih adil, manusia yang lebih religius, manusia yang lebih spiritual. Ini pula saatnya kita menjadi oase di tengah padang gurun krisis lingkungan alam yang mendera tubuh alam kita saat ini.

Kita berusaha hidup menjadi manusia spiritual-ekologis. Pribadi Spiritual-Ekologis hidup mengintegrasikan segala sesuatu dalam alam dengan mengubah persepsi atas dunia alam semesta dan menyatukan realitas dengan subjektivitas dirinya. Alam bukan sesuatu yang aneh dan asing di luar sana, tapi sahabat dan kawan yang akrab dan menyatu dengan diri kita. Namun, Masihkah Pribadi Spiritual Ekologis menjadi seksi di tengah semaraknya praktik dunia industri kapitalis dan dahsyatnya arus utama (mainstream) perayaan gaya hidup glamour mengejar logika kemajuan ekonomi dewasa ini yang cenderung bergerak ke arah sikap antiterang atau bahkan kontraterang itu?

Kita dapat menjadi manusia spiritual ekologis. Manusia spiritual-ekologis dapat kita terapkan dengan berkomitmen untuk memiliki pandangan yang melampau realitas fisik ini. Itu dapat kita capai dengan memiliki pemahaman spiritual/rohani yang tinggi berbasis agama dan nilai spiritualitas. Manusia spiritual ekologis berisikan spirit kesatuan (oneness) dengan segala entitas lain dalam alam.

Manusia spiritual-ekologis masih seksi. Ia menjadi suatu konsep yang aplikatif secara sukarela dalam pribadi-pribadi yang menghayati hidup penuh komitmen pada kebaikan alam dan others. Namanama seperti Bill Gates (pemilik Microsoft) maupun orang kaya dunia lainnya seperti Warren Buffet, William Hewlett, David Packard, Ted Turner, George Soros adalah pribadi-pribadi yang berkomitmen tinggi peduli pada kebaikan others dengan mendirikan banyak komunitas foundation di awal abad ke-21 ini. Mereka adalah pemilik usaha yang terkenal menyalurkan bantuan sosial kepada kebaikan others: manusia dan lingkungan alam. Ini membuktikan bahwa manusia spiritual-ekologis itu masih seksi dan masih ada, Manusia spiritual etis dapat dihayati oleh pribadi-pribadi yang sukarela melakukan kebaikan dan keadilan kendatipun berasal dari kelompok masyarakat elit pemilik bisnis berskala dunia dunia.

Bagi kaum religius, kita dapat mereaktualisasikan kembali makna hidup sederhana (ugahari) dalam hidup kita. Kita harus menunjukkan 
cara hidup sederhana sebagai suatu cara hidup spiritual yang anggun di tengah perayaan materialisme masyarakat industri pasar masa kini. Dengan hidup sederhana, maka kita menunjukkan diri sebagai pribadi manusia yang berkarakter hijau (green character person). Di sinilah kita dapat menjadi pribadi yang peduli pada entitas others, sehingga dapat menjadi alternatif menjawab krisis manusia zaman industri dewasa ini. Manusia spiritual-ekologis dapat menjadi 'subjek seksi' yang memberikan harapan di tengah seronoknya dominasi pola hidup manusia modern yang cenderung bergaya hidup konsumeristis dan hedonistis. Dengan menjadi manusia spiritual-ekologis, kita dapat menjadi 'setitik oase' yang menumbuhkan optimisme hidup dan membangkitkan fajar harapan bahwa kita manusia bisa mengonstruksikan model interaksi yang lebih ideal (baik dan adil) dengan komunitas lingkungan ekologis di mana saja kita berada. Maka kita manusia seharusnya mampu membangun relasi spiritual dengan alam. Ini bukan suatu konsep berpikir yang utopis, melainkan suatu paradigma spiritual yang dapat diaplikasikan secara nyata dalam hidup kita. Karena kita, setiap subjek manusia masih memiliki kesadaran moral dan jiwa spiritual-religius yang mengkristal langgeng di relung hati kita yang otentik. Itulah kualitas terang yang bisa kita sadari dan kita berdayakan agar kita mampu mengada secara bermakna dalam bentangan alam semesta yang terus berevolusi secara anggun ini. Kita manusia mampu berpikir bijak, mampu sadar secara spiritual di dalam jiwa, dan mampu bertindak bijak dalam hidup untuk semakin berinteraksi secara ekologis dengan alam.

Kita tetaplah diingatkan bahwa manusia spiritual-ekologis tidak selesai hanya pada tataran pemikiran metafisik-epistemologis saja. Ataupun hanya sampai pada ranah konseptual-ideologis belaka. Tetapi yang terpenting, adalah keberanian untuk melakukan transformasi sikap dan karakter diri secara kontekstual-aktual ke dalam ruang-ruang kehidupan kita yang paling nyata di dalam kebersamaan dengan entitas others. Kita perlu mengubah diri, sebab jika tidak, cepat atau lambat manusia dan alam akan sama-sama hancur dan rusak. Polusi udara akan semakin bertambah sehingga suatu ketika kita tidak bisa lagi menghirup udara sehat secara gratis. Dan setiap kita akan memikul tabung gas udara di pundak kita masingmasing ketika berjalan di atas lorong-lorong jalanan di permukaan bumi ini. Saat bumi ini sudah terpolusi parah, kita manusia akan bermigrasi ke planet lain seperti ke Bulan, Mars ataupun Yupiter. Namun ketika kita sampai di sana, dipastikan tidak ada kualitas kehidupan ekologis yang bisa menopang potensi kita untuk hidup. Karena sejauh ini hanya bumi yang bisa memberikan kehidupan kepada kita, hewan dan tumbuh-tumbuhan. Kita akhirnya mati, punah dan binasa dalam bentangan alam semesta ini. Ketika kita mati, alam tetap ada, karena alam itu disebabkan oleh roh. Tidak ada pilihan lain bagi kita manusia. Mau atau tidak, suka atau tidak, kita seyogyanya perlu memilih untuk hidup seksi dengan menjadi pribadi manusia spiritual-ekologis. Sebab hanya dengan cara ini, kita merawat diri, kita menjaga alam, kita melanggengkan evolusi kosmos untuk terus berlanjut menuju hamparan masa depan yang terbuka, anggun namun indah ini.

\section{Kesimpulan}

Krisis yang menimpa alam lingkungan bukan saja krisis terhadap alam itu sendiri, terlepas dari kita subjek manusia. Krisis itu bukan saja krisis 
realitas eksternal alam in se, melainkan juga suatu krisis yang menyentuh dimensi spiritual kemanusiaan kita sendiri sebagai manusia yang memiliki kepekaan moral dan intuisi religius spiritual dalam hakikat diri kita.

Krisis alam dilecut oleh pola pikir materialistik yang dibangun di atas dasar logika pandangan manusia atas dunia yang atomistikmekanistik. Alam terpisah dari manusia dan oleh karena itu lantas dijadikan sebagai objek eksploitasi. Padahal alam adalah diri kita sendiri sebagai manusia. Kita hidup, ada dan berkembang serta bertumbuh di dalam alam dan bersama dengan alam. Bahkan diri kita sendiri masing-masing sesunguhnya adalah alam itu sendiri. Karena kita menerima kehidupan dan pertumbuhan dari alam yang adalah sumber kehidupan esensial diri kita sendiri. Kita adalah mikrokosmos dari entitas alam yang adalah makrokosmos lebih luas dari kita. Kalau alam rusak, itu pratanda atau lonceng kehancuran dan kerusakan bagi diri kita sendiri sebagai manusia karena kita adalah bagian dari alam dan kitalah alam itu sendiri pula.

Maka untuk hidup secara spiritual dengan alam kita perlu mengubah cara pandang kita yang materialis menuju yang pemahaman yang spiritual. Bahwa alam ini memiliki jiwanya sendiri. Alam dihadirkan bukan oleh yang fisik dan mekanistik, melainkan oleh yang non fisik, roh, yang metafisik. Di sini kita perlu sadar bahwa ada suatu realitas ada yang tak berhingga, ada suatu metafisika kehadiran yang tidak dapat dipahami secara penuh dan tidak dapat dilihat secara langsung di balik realitas fisik yang kelihatan ini. Dialah yang menghadirkan segala ada dalam alam semesta ini termasuk kita manusia dan segala makhluk lain; human maupun infrahuman. Dialah nilai absolut yang menjiwai, meresapi, mendasari dan menyebabkan adanya alam dan manusia.

Di titik ini hanyalah kerendahan hati yang dibutuhkan oleh manusia modern untuk mengakui adanya spiritualisme alam sebagai realitas yang melampaui yang fisik. Kerendahan hati untuk mengakui dimensi spiritual alam akhirnya menjadi suatu iman filosofis-teologis kita dalam ikhtiar menjadi manusia spiritual-ekologis dalam tatanan alam dunia yang terus berevolusi ini. Bahwa kita memiliki keterbatasan untuk memahami asal usul alam, dan ke mana alam ini akan pergi dan kapan ia akan berakhir? Akhirnya bersama Einstein kita hanya dapat berseru: "Kita manusia hanyalah salah satu butiran kecil dan satu partikel terkecil di dalam bentangan alam semesta yang mahaluas dan tak terpahami ini”.

\section{Daftar Pustaka}

Bochert, D (ed.). 2006. Encyclopedia of Philosophy Volume 3 (Detroit: Thomson Gale).

Fios, Frederikus (2013). Pengantar Filsafat:

Ilmu dan Logika (Jakarta: Salemba Humanika)

Fios, Frederikus \& Gea Antonius (2017).

Character Building: Spiritual Development.

(Jakarta: Binus Media \& Publishing)

Gorke, Martin (2003) The Death of Our Planet

Species (Washington, Covelo, London:

Island Press)

Heidegger, Martin (trans.) John Macquarrie and

Edward Robinson (1962). Being and Time.

San Francisco: Harper San Francisco.

Marshal, Allan (2002) The Unity of Nature (London: Imperial College Press). 
Maslow, Abraham (terj.) (1992) Religion, Debate). New York: Fordham University Values and Peak Experience (LPBAJ: Press.

Maumere). Naess, Arne (1989) Ecology, Tucker, Evelyn Mary \& Grim, A John (2003).

Community and Life Style, (Cambridge-UK, Worldviews and Ecology: Religion,

Cambridge University Press) Philosophy, and the Environment (New

Roy. E. Allen (2007) Human Ecology York: Orbis Book).

Economics (London \& New York: Zohar, Danah \& Marshall. Ian (2007) "SQ:

Routledge) Spiritual Intelligence, Ultimate Intelligence”.

Singh, Vir (1991) My Poland Diary, London: Bloomsbury.

unpublished paper diakses 11 Maret 2015 http://nationalgeographic.co.id/berita/2015/09/h

Skolimowski, Henryk (1981). Eco-Philosophy: utan-indonesia-telah-hilang-40-persen,

Designing New Tactics for Living. Boston: diakses 5 April 5, 2016.

M. Boyars

Skolimowski, Henryk (1993), A Secret Place to

http://www.antaranews.com/print/26789/luas-

hutan-di-pulau-jawa-tinggal-11-persen,

Dwell, Element Books.

diakses April 5, 2016.

Spinoza, Baruch (Yosep Ratner ed.) (2010). http://www.antaranews.com/print/250882/menh

Philosophy of Spinoza. Produced by Alicia ut-tutupan-hutan-di-sumatera-tinggal-10-

Williams and the Online Distributed persen, diakses April 5, 2016.

Proofreading Team at http://www.pgdp.net, "Hoyle on the Radio: Creating the 'Big Bang"'.

[EBook \#31205, Retreived February 7, 2010 BBC News. Archived from the original on

Teanor, Brian (2006) Aspects of Alterity 26 May 2014, diakses September 4, 2017.

(Levinas, Marcel and the Contemporary 